\title{
Characterisation of proghrelin peptides in mammalian tissue and plasma
}

\author{
Angela S Bang, Steven G Soule', Tim G Yandle, A Mark Richards and Chris J Pemberton \\ Christchurch Cardioendocrine Research Group, Department of Medicine, ${ }^{1}$ Department of Endocrinology, Christchurch School of Medicine and Health Sciences, \\ University of Otago, PO Box 4345, 8140 Christchurch, New Zealand \\ (Requests for offprints should be addressed to C J Pemberton; Email: chris.pemberton@chmeds.ac.nz)
}

\begin{abstract}
Ghrelin is a 28 amino acid stomach peptide, derived from proghrelin(1-94), that stimulates GH release, appetite and adipose deposition. Recently, a peptide derived from proghrelin(53-75) - also known as obestatin - has been reported to be a physiological antagonist of ghrelin in the rat. Using four specific RIAs, we provide the first characterisation of proghrelin(1-94) peptides in human plasma, their modulation by metabolic manipulation and their distribution in mammalian tissues. ghrelin(1-28) immunoreactivity (IR) in human plasma and rat plasma/stomach consisted of major des-octanoyl and minor octanoylated forms, as determined by HPLC/RIA. Human plasma ghrelin(1-28) IR was significantly suppressed by food intake, oral glucose and $1 \mathrm{mg}$ s.c. glucagon administration. ghrelin(1-28) IR and proghrelin(29-94) IR peptide distributions in the rat indicated that the stomach and gastrointestinal
\end{abstract}

tract contain the highest amounts of the peptides. Human and rat plasma and rat stomach extracts contained a major IR peak of proghrelin(29-94)-like peptide as determined by HPLC/RIA, whereas no obestatin IR was observed. Human plasma proghrelin(29-94)-like IR positively correlated with ghrelin(1-28) IR, was significantly suppressed by food intake and oral glucose and shared with ghrelin(1-28) IR a negative correlation with body mass index. We found no evidence for the existence of obestatin as a unique, endogenous peptide. Rather, our data suggest that circulating and stored peptides derived from the carboxyl terminal of proghrelin (C-ghrelin) are consistent in length with proghrelin(29-94) and respond to metabolic manipulation, at least in man, in similar fashion to ghrelin(1-28).

Journal of Endocrinology (2007) 192, 313-323

\section{Introduction}

The discovery of ghrelin as an endogenous, stomach-derived ligand that can activate the growth hormone secretagogue receptor-1a (GHS-R1a) at physiological concentrations has provided novel insights into regulation of growth hormone (GH) secretion, appetite and metabolism (Kojima et al. 1999, Korbonits et al. 2004, Sun et al. 2004, van der Lely et al. 2004). ghrelin is formed by enzymatic cleavage between amino acids $\mathrm{Arg}^{28} / \mathrm{Ala}^{29}$ of proghrelin(1-94) and the novel post-translational addition of an n-octanoic moiety to $\operatorname{Ser}^{3}$ (Kojima et al. 1999). This addition is thought to account for approximately $50 \%$ of stored and $10 \%$ of circulating ghrelin in humans and rodents (Hosoda et al. 2000, Shiiya et al. 2002), suggesting that the $n$-octanoic acid moiety is rapidly degraded upon secretion from stomach cells. In the rat (Hosoda et al. 2000), immunoreactive (IR) ghrelin(1-28) peptides are most abundant in the stomach, followed by the duodenum, ileum and jejunum. Deposits of ghrelin IR are also found in the submaxillary gland, kidney, thyroid, hypothalamus and pituitary.

Early reports suggested that $\mathrm{Ser}^{3}$-octanoylation was obligatory for ghrelin induced increases in GH release and adipose deposition (Kojima et al. 1999, Tschop et al. 2000, Wren et al. 2000), but des-octanoyl ghrelin, which does not stimulate GH-release, may also influence feeding and metabolism in vivo (Broglio et al. 2004, Thompson et al. 2004, Toshinai et al. 2006). The total plasma concentrations of ghrelin in humans are negatively correlated with body mass index (BMI; Tschop et al. 2001, Shiiya et al. 2002) and are suppressed by nutritional intake (Cummings et al. 2001) or glucose administration alone (Shiiya et al. 2002). However, the in vivo physiological contributions of putative ghrelin secretagogues, including insulin, glucagon and leptin remain unclear or controversial (Korbonits et al. 2004, Soule et al. 2005).

We have previously described immunoreactive peptide(s) derived from the carboxyl terminus (C) of proghrelin(1-94) (C-ghrelin) in the human circulation (Pemberton et al. 2003). More recently, a putative stomach peptide derived from the carboxyl terminus of rat $\mathrm{C}$-ghrelin, named obestatin, was reported (Zhang et al. 2005). The structure of obestatin was deduced by amino acid sequencing of a purified 20 residue peptide sequence, combined with mass spectrometry data, to generate a 23 amino acid sequence (proghrelin(53-75)). Amidation of obestatin was assumed, but not verified, on the basis of a C-terminal Gly-Lys motif (Zhang et al. 2005). 
Subsequent in vitro and in vivo analysis suggested that amidated obestatin could suppress food intake, inhibit jejunal contraction and decrease body weight gain in rats via activation of the G-protein-coupled receptor GPR39. Surprisingly, plasma concentrations of obestatin were not modified by fastingfeeding manipulations in rats (Zhang et al. 2005) and GPR39 receptor transcripts show variable expression in hypothalamus tissue across species (Zhang et al. 2005, Jackson et al. 2006, Nogueiras et al. 2006).

The existence of obestatin in the human circulation has not been reported and whether it responds to metabolic manipulations in similar fashion to ghrelin is also unknown. Furthermore, the distribution and molecular forms of obestatin and other putative carboxyl terminal proghrelinderived peptides in mammalian tissues and plasma has not been reported. Accordingly, we provide here: (i) documentation of the distribution and molecular forms of IR peptides derived from proghrelin(1-94) in rat tissues and plasma, (ii) the first description of plasma levels and molecular forms of proghrelin(1-94) peptides in the human circulation and (iii) the first human studies documenting the response of circulating carboxyl terminal proghrelin/obestatin-like peptides to fasting/feeding and metabolic manipulations.

\section{Materials and methods}

All human protocols were approved by the Upper South Regional Ethics Committee of the Ministry of Health, New Zealand functioning in accordance with the Guidelines on the Practice of Ethical Committees in Medical Research, 3rd ed. and all subjects gave full, informed consent. All animal investigations conformed to the UFAW Handbook on the Care and Management of Laboratory Animals.

\section{Chemicals}

Synthetic human and rat proghrelin(63-94) and proghrelin(53-75) (obestatin) peptides were obtained from Phoenix Pharmaceuticals (Belmont, CA, USA). Peptides derived from human proghrelin(29-40) were obtained from Auspep (Parkville, Australia). All buffer reagents were purchased from $\mathrm{BDH}$ and/or Sigma.

\section{Human endocrine studies}

Four human studies were performed: (i) IR proghrelin reference range study, (ii) overnight fasting/feeding replacement study, (iii) oral glucose loading and (iv) s.c. glucagon stimulation. For all studies, healthy human volunteers presented to the endocrine clinic at $0800 \mathrm{~h}$ after an overnight 12-h fast. Exclusion criteria were previous gastric surgery, cardiovascular, endocrine or psychiatric illness, use of prescribed medications, including $\mathrm{H}_{2}$-receptor antagonists, proton pump inhibitors and diabetes mellitus.
For the healthy volunteer reference range study, blood samples were obtained from 56 healthy volunteers (35 women) with an average age of $47 \pm 2$ years (range 19-73 years) and BMI of $25 \cdot 7 \pm 0 \cdot 7 \mathrm{~kg} / \mathrm{m}^{2}$. For the fasting/feeding replacement study, eight healthy volunteers (four women) with an average age of $47 \pm 8$ years and BMI of $22 \cdot 8 \pm$ $2.6 \mathrm{~kg} / \mathrm{m}^{2}$ received at $0830 \mathrm{~h}$ a test meal of 450 calories containing $50 \%$ carbohydrate, $30 \%$ fat and $20 \%$ protein. Blood samples were drawn at -15 and 0 min pre-meal, then $+30,+60,+90,+120$ and +150 min post-meal for the measurement of proghrelin peptides, insulin and glucose. All samples were kept on ice until centrifugation at $4{ }^{\circ} \mathrm{C}$ with plasma then stored at $-80^{\circ} \mathrm{C}$ until RIA. For oral glucose tolerance testing (OGTT), 11 volunteers ( 5 women) with a mean age of $47 \pm 3$ years and BMI of $23 \cdot 5 \pm 0 \cdot 8 \mathrm{~kg} / \mathrm{m}^{2}$ drank a $200 \mathrm{ml}$ solution containing $75 \mathrm{~g}$ glucose or $200 \mathrm{ml}$ water on separate days, between 0800 and $0830 \mathrm{~h}$. Venous blood was drawn at $t=-10,0,15,30,45,60,90$ and $120 \mathrm{~min}$, centrifuged at $4{ }^{\circ} \mathrm{C}$ and plasma stored at $-80{ }^{\circ} \mathrm{C}$ until specific assay for proghrelin peptides. Glucagon stimulation testing was carried out as previously described (Soule et al. 2005). Briefly, nine volunteers (three women) of mean age $47 \pm 4$ years and BMI $24 \cdot 1 \pm 0.9 \mathrm{~kg} / \mathrm{m}^{2}$ presented at $0800 \mathrm{~h}$ and received, in a non-randomised unblinded fashion, $1 \mathrm{mg}$ glucagon in $1 \mathrm{ml}$ saline or $1 \mathrm{ml}$ saline s.c. Venous blood samples were taken at $t=0,15,30,45,60,90,120,150,180$, 210 and $240 \mathrm{~min}$ post-administration. Plasma samples for RIA were immediately processed and stored at $-80^{\circ} \mathrm{C}$.

\section{Rat tissue and plasma collection}

Six adult male Sprague-Dawley rats (250-325 g) were housed under controlled conditions and fasted for 12-h overnight. Animals were anaesthetised with $50 \mathrm{mg} / \mathrm{kg}$ sodium pentobarbital i.p., decapitated and trunk blood was collected into chilled $\mathrm{Na}^{3}$-EDTA tubes. Plasma was then prepared by centrifugation and stored at $-80{ }^{\circ} \mathrm{C}$ prior to RIA. Thyroid, submaxillary gland, atrium, left ventricular free wall, stomach, duodenum, pituitary, colon, kidney, thymus and adrenal tissue samples were rinsed in the ice-cold saline, weighed and quickly frozen at $-80{ }^{\circ} \mathrm{C}$ prior to extraction and RIA.

\section{Tissue and plasma extraction}

Rat tissue extracts were prepared as previously described (Pemberton et al. 2004). Briefly, rat tissue samples were thawed on ice, diced and boiled gently in ten volumes of distilled water for 4-5 $\mathrm{min}$ to inactivate intrinsic proteases. After cooling on ice, samples were adjusted to $1 \mathrm{M}$ acetic acid/20 $\mathrm{mM} \mathrm{HCl}$ and homogenised for $1 \mathrm{~min}$ at high speed. Supernatants obtained from centrifugation at 4000 r.p.m./ $4{ }^{\circ} \mathrm{C}$ for $20 \mathrm{~min}$ were lyophilised and frozen at $-80{ }^{\circ} \mathrm{C}$ prior to RIA and/or HPLC. Recovery of synthetic ghrelin(1-28), obestatin and proghrelin(63-94) added to tissue samples prior to boiling/homogenisation was $72 \pm 3,81 \pm 4$ and $68 \pm 8 \%$ respectively ( $n=4$ for each peptide). All plasma samples 
(rat and human) were extracted on SepPak cartridges as previously described (Pemberton et al. 2004), dried and stored at $-20{ }^{\circ} \mathrm{C}$ prior to RIA and HPLC. The recovery of synthetic human and rat obestatin, ghrelin(1-28) and proghrelin(63-94) added to plasma and extracted using our procedures was $83 \pm 10,73 \pm 5$ and $66 \pm 4 \%$ respectively ( $n=5$ for each peptide).

\section{Hormone concentration analysis}

Plasma insulin was determined by the Roche Elecsys two-site system (Roche Diagnostics). The detection limit for this assay was $2.5 \mathrm{pmol} / 1$ and the inter-assay coefficient of variation $(\mathrm{CV})<5 \%$ between 64 and $860 \mathrm{pmol} / 1$. Plasma glucose was determined on an Abbott Aeroset Analyser (Abbott Systems). GH was determined by IRMA (Bioclone, Marrickville, $\mathrm{NSW}$, Australia) with a detection limit of $0.19 \mu \mathrm{g} / \mathrm{l}$ and interassay $\mathrm{CV}<10 \%$ between 1.8 and $5.9 \mu \mathrm{g} / \mathrm{l}$.

In order to determine the concentrations of multiple potential peptides derived from proghrelin(1-94), we employed four specific RIAs that utilised antisera directed against four regions of the proghrelin(1-94) sequence (Fig. 1A). Cross-reactivity data for each of these assays are given in Table 2.

A
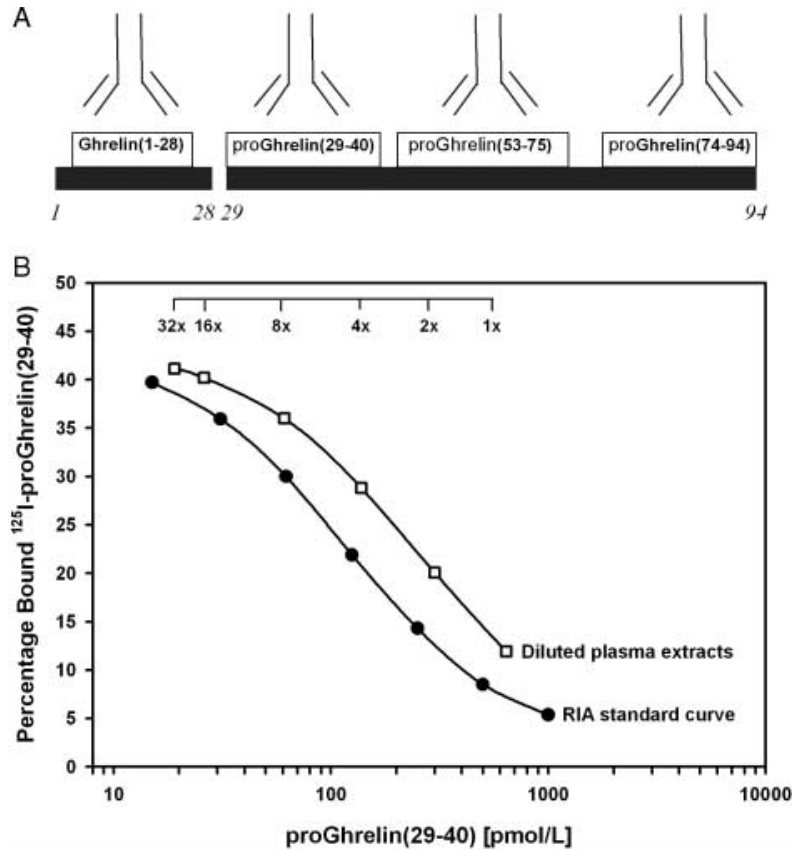

Figure 1 (A) Four antibody/RIA approach to the study of putative proghrelin(1-94) peptides. Antibodies generated against the regions shown were used to establish specific RIAs for the detection of putative proghrelin(1-94) peptides in tissues and plasma. (B) Representative dilution curve of a concentrated plasma extract drawn from a healthy volunteer (open squares, numbers above square indicate dilution factor) measured against the proghrelin (29-40) RIA standard curve (filled circles). Both curves are drawn on $\log _{10}$ scale.
Ghrelin(1-28) and proghrelin(74-94) RIAs Plasma ghrelin concentrations in human plasma were determined as previously reported (Pemberton et al. 2003, Soule et al. 2005), using an antibody that was $100 \%$ cross-reactive with octanoyl and des-octanoyl human ghrelin(1-28). Inter- and intra-coefficient of variation between 50 and $220 \mathrm{pmol} / 1$ for this assay were 11.4 and $9 \cdot 2 \%$ respectively. Rat ghrelin(1-28) concentrations were determined in the same RIA format as for human samples, utilising a commercial anti-rat ghrelin(128) antibody and standards (Bachem, Lausanne, Switzerland) that had $1 \%$ cross-reactivity with human ghrelin(1-28). Human proghrelin(74-94) IR was determined as previously described (Pemberton et al. 2003). For rat samples, proghrelin(74-94) levels were determined against rat proghrelin(74-94) standards (0-28 $000 \mathrm{pmol} / \mathrm{l})$ using our previously described antiserum A14 (Pemberton et al. 2003) at a final dilution in the ratio of 1:3000. For this assay, interand intra-coefficient of variations between 100 and $3000 \mathrm{pmol} / 1$ were 8.2 and $<5 \%$ respectively.

Proghrelin(29-40) RIA For the measurement of putative proghrelin(29-40) IR peptides, we generated a novel and specific RIA directed against amino acids 29-40 of the human proghrelin(1-94) sequence.

Proghrelin(29-40)-C $y s^{41}$ was coupled to malemide treated/N-e-maleimid D caproyloxy sulfosuccinimide ester (EMCS) derivatised BSA in PBS $(\mathrm{pH} 7 \cdot 0)$ by gentle mixing at room temperature. Coupled peptide was emulsified with Freund's adjuvant and injected subcutaneously in two New Zealand white rabbits over four to five sites at monthly intervals. Rabbits were bled 12 days after injection to assess antibody $(\mathrm{Ab})$ titres until adequate levels were achieved. For RIA, proghrelin(29-40) IR was determined using antiserum I32 at a final dilution in the ratio of 1:15000.

Proghrelin(29-40)-Ty ${ }^{41}$ was iodinated via the Chloramine T method and purified on reverse phase HPLC as previously described (Pemberton et al. 2004). All samples, standards, radioactive traces and antiserum solutions were diluted in sodium-based assay buffer (Pemberton et al. 2003). The assay incubate consisted of $100 \mu \mathrm{l}$ sample or standard $(0-1000 \mathrm{pmol}$ human proghrelin(29-40)) combined with $100 \mu \mathrm{l}$ antiserum which was vortexed and incubated at $4{ }^{\circ} \mathrm{C}$ for $24 \mathrm{~h}$. Then, $100 \mu \mathrm{l}$ traces $(4000-5000$ c.p.m.) were added and further incubated for $24 \mathrm{~h}$ at $4{ }^{\circ} \mathrm{C}$. Free and bound immunoreactivities were finally separated by the solid-phase second antibody method (donkey anti-rabbit Sac-Cel) and counted in a Gammamaster counter (LKB, Uppsala, Sweden).

Obestatin/proghrelin(53-75) RIA measurements in human and rat samples Obestatin (proghrelin(53-75)) immunoreactivities in (1) human plasma and (2) rat plasma and tissue samples were determined using commercially available species appropriate RIAs, according to the manufacturer's instructions (Phoenix Pharmaceuticals, Belmont, CA, USA). All standards, radioactive tracer and 
antiserum solutions were diluted in the RIA buffer provided by the manufacturer.

\section{HPLC}

Stomach tissue and plasma extracts were subjected to sizeexclusion HPLC (SE-HPLC) at room temperature on a TSKGel G2000SW peptide column (Toyosoda, Tokyo, Japan) using isocratic conditions of $60 \%$ acetonitrile $/ 0 \cdot 1 \%$ trifluoroacetic acid (TFA) at a flow rate of $0 \cdot 25 / \mathrm{ml}$ per min. Fractions were collected at 1-min intervals and subjected to proghrelin RIA. The SE-HPLC column was calibrated using dextran blue (Vo), cytochrome C $\left(\mathrm{M}_{\mathrm{r}} \sim 12400\right)$, aprotinin $\left(\mathrm{M}_{\mathrm{r}} \sim 6500\right)$, obestatin(53-75; $\left.\mathrm{M}_{\mathrm{r}} \sim 2500\right)$, urotensin II $\left(\mathrm{M}_{\mathrm{r}} \sim 1600\right)$ and glycine $(\mathrm{Vt})$. proghrelin-derived peptides identified by SE-HPLC/RIA were then further characterised on a Brownlee $\mathrm{C}_{18}$ reverse-phase HPLC (RP-HPLC) column (Applied Biosystems, Foster City, CA, USA) with a linear eluting gradient from 20 to $60 \%$ acetonitrile $/ 0 \cdot 1 \%$ TFA over $40 \mathrm{~min}$, at a flow rate of $1 \mathrm{ml} / \mathrm{min}$. Fractions were collected at 1-min intervals, dried under an air stream and subjected to specific RIA as for SE-HPLC. RP-HPLC was calibrated using synthetic amidated obestatin(53-75), octanoyl ghrelin(1-28) and des-octanoyl ghrelin(1-28).

\section{Statistical analysis}

All results are presented as means \pm S.D. Comparison of tissue concentrations of proghrelin peptide means was carried out using paired, two-tailed Student's $t$-test. Time-course data from human endocrine studies were analysed using two-way ANOVA for repeated measurements followed by least significant difference post hoc testing. Correlation analysis of plasma hormone concentrations was carried out using a general linear regression model. In all analyses, a $P$ value $<0 \cdot 05$ was considered significant.

\section{Results}

\section{Characteristics of proghrelin peptide RIAs}

The newly developed RIA for human C-ghrelin (proghrelin(29-40)) had a zero binding of $51 \cdot 6 \pm 0 \cdot 3 \%$, detection limit of $9 \cdot 8 \pm 2 \cdot 2 \mathrm{pmol} / 1$, effective displacement $(\mathrm{ED})_{50}$ of $122 \cdot 2 \pm 4 \cdot 6 \mathrm{pmol} / 1$ and a non-specific binding of $3 \cdot 9 \pm 0 \cdot 1 \%$ over 12 assays. Serial doubling dilution of human plasma extracts was in parallel with the assay standard curve (Fig. 1B). Inter- and intra-assay coefficient of variations between 50 and $250 \mathrm{pmol} / 1$ for this assay were $<9$ and $5 \%$ respectively. The RIA for human obestatin had a zero binding of $24 \cdot 5 \pm 0 \cdot 2 \%$, detection limit of $30 \cdot 4 \pm 2 \cdot 0 \mathrm{pmol} / 1, \mathrm{ED}_{50}$ of $241 \cdot 8 \pm$ $10 \cdot 2 \mathrm{pmol} / 1$ and a non-specific binding of $1 \cdot 3 \pm 0 \cdot 1 \%$ over three assays. The RIA for rat obestatin had a zero binding of $39 \cdot 2 \pm 1 \cdot 4 \%$, detection limit of $19 \cdot 4 \pm 1 \cdot 4 \mathrm{pmol} / 1, \mathrm{ED}_{50}$ of $336 \cdot 3 \pm 9 \cdot 8 \mathrm{pmol} / 1$ and a non-specific binding of $1 \cdot 2 \pm 0 \cdot 1 \%$ over four assays.
Molecular forms of proghrelin peptides in human plasma

Proghrelin(74-94) and proghrelin(29-40) SE-HPLC/RIA analysis of human plasma extracts detected a single, major IR peak with a molecular mass $\sim 7000$, consistent in size with full length human proghrelin(29-94) (Fig. 2A). The C-ghrelin(74-94) RIA also detected a minor IR peak at $M_{r} \sim 10000$. No IR was detected consistent in size with putative proghrelin(29-52) or proghrelin(76-94) peptides in SE-HPLC profiles. The obestatin(53-75) RIA detected a single IR peak at $\mathrm{M}_{\mathrm{r}} \sim 7000$ in SE-HPLC fractions but did not detect any IR peaks in the molecular mass range $\sim 1000$ 3000 (Fig. 2B). Ghrelin(1-28) RIA analysis of plasma extracts detected two peaks: a minor component at $\mathrm{M}_{\mathrm{r}} \sim 10000$ and a major peak eluting consistent with synthetic ghrelin(1-28) at $\mathrm{M}_{\mathrm{r}} \sim 3000$ (Fig. 2B).

RP-HPLC analysis of IR C-ghrelin observed on SE-HPLC also detected a single peak that was immunoreactive with both proghrelin(29-40) and proghrelin(74-94) RIAs (Fig. 2C). The small peak on SE-HPLC at $\mathrm{M}_{\mathrm{r}} \sim 10000$ that was immunoreactive with proghrelin(74-94) and ghrelin(1-28) RIAs was not analysed further and assumed to be proghrelin(1-94)-like material. obestatin immunoreactivity identified on SE-HPLC eluted as two peaks on RP-HPLC, the first (and major) of which eluted consistent with IR C-ghrelin identified in Fig. 2C, with the second peak eluting three fractions later (Fig. 2D). No peaks eluting consistent with synthetic human obestatin (proghrelin(53-75)) were observed. ghrelin(1-28) IR of $\mathrm{M}_{\mathrm{r}} \sim 3000$ SE-HPLC almost totally comprised des-octanoylated ghrelin(1-28) on RP-HPLC, with a small component eluting consistent with the octanoyl form (Fig. 2D).

\section{Plasma concentrations of proghrelin peptides in fasted, healthy} human volunteers

Since the proghrelin(29-40) RIA detected a single molecular species of C-ghrelin in human plasma and did not cross-react with the proghrelin(1-94)-like peptide observed by the proghrelin(74-94) RIA, all C-ghrelin measurements in human studies were performed with our 'in house' proghrelin(29-40) assay.

The mean plasma concentration of ghrelin(1-28) IR in 56 healthy, fasted volunteers $(293 \pm 171 \mathrm{pmol} / \mathrm{l})$ was significantly higher than that of proghrelin(29-40) IR (114 $\pm 71 \mathrm{pmol} / \mathrm{l}$, $P<0 \cdot 01$ versus ghrelin(1-28)). However, IR ghrelin(1-28) and IR C-ghrelin concentrations both held significant negative correlations with BMI $(P<0 \cdot 05$, Fig. $3 \mathrm{~A}$ and $\mathrm{B})$, but not with age or gender. Furthermore, plasma $\mathrm{C}$-ghrelin and ghrelin(1-28) IR had a strong positive correlation $(P<0 \cdot 001$, Fig. 3C).

\section{Concentrations of proghrelin peptides in human plasma: response} to endocrine manipulation

Plasma glucose and insulin concentrations were significantly increased within $30 \mathrm{~min}$ of feeding and returned to near 

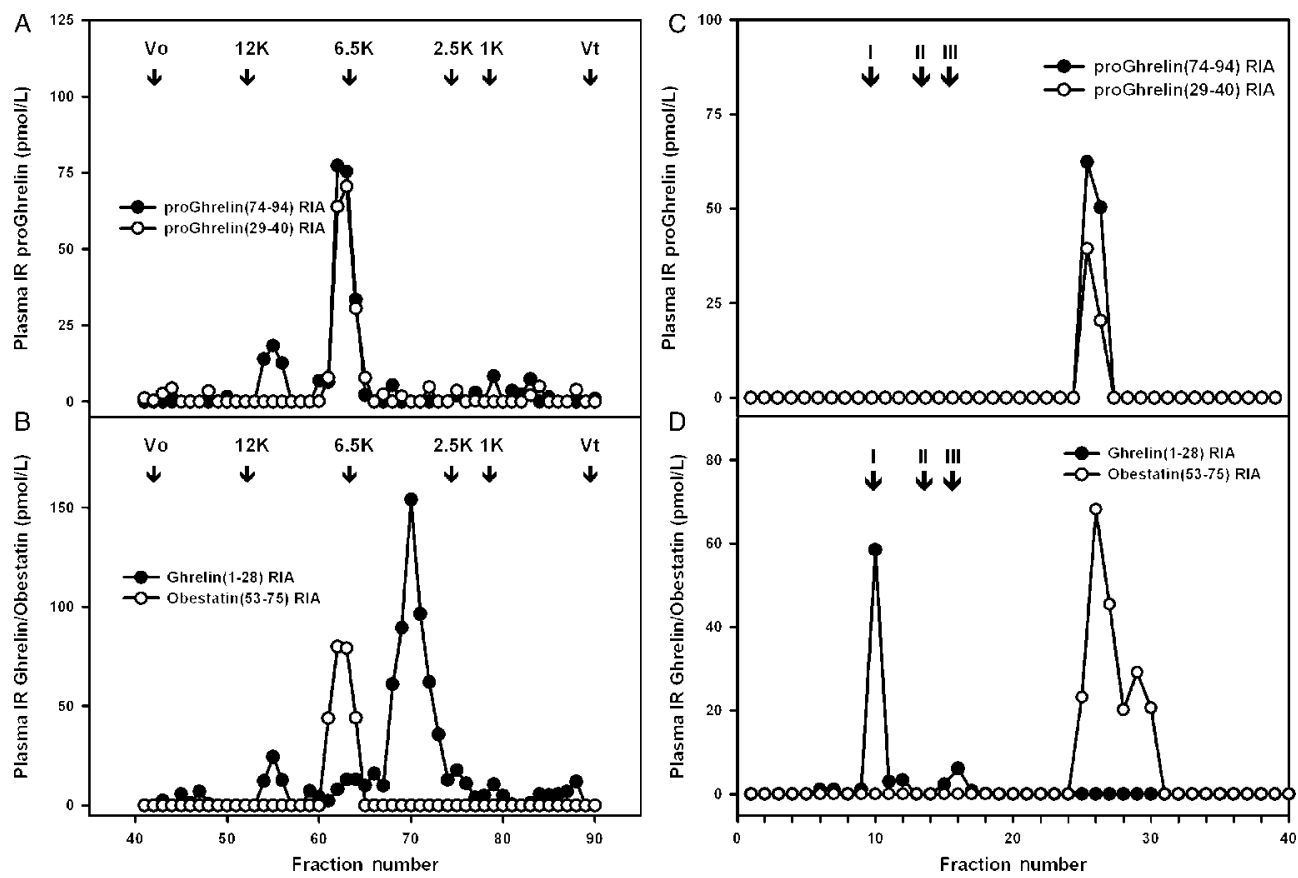

Figure 2 SE-HPLC/RIA and RP-HPLC/RIA profiles of IR proghrelin peptides in human plasma. The proghrelin(29-40) and proghrelin(74-94) RIAs both detected a major IR peak at $\mathrm{M}_{\mathrm{r}} \sim 7000$ on SE-HPLC (A) which eluted as a single peak on subsequent RP-HPLC (C). The obestatin(53-75) RIA detected a single IR peak at $\mathrm{M}_{\mathrm{r}} \sim 7000$ on SE-HPLC (B) which eluted as two peaks on RP-HPLC (D), at similar times to those observed in (C). No obestatin(53-75) IR was observed on SE-HPLC or RP-HPLC profiles. IR ghrelin(1-28) eluted on SE-HPLC as a major peak at $M_{r} \sim 3000$ and a minor peak at $M_{r} \sim 10000$ (B). The major $M_{r} \sim 3000$ ghrelin(1-28) peak eluted on RP-HPLC as a major peak at the position of des-octanoyl ghrelin with a minor component at the octanoyl form position (D). The minor IR $M_{r} \sim 10000$ ghrelin(1-28) peak on SE-HPLC eluted consistent with that observed by the proghrelin(74-94) RIA (A and B) and was concluded to be proghrelin(1-94)like material. In C and D I, II and III are the elution positions of synthetic human des-octanoyl ghrelin, obestatin and octanoyl ghrelin peptides respectively.

fasting levels by $150 \mathrm{~min}$ in healthy human volunteers (Fig. 4A). Mean fasting plasma concentrations of ghrelin $(364 \pm 212 \mathrm{pmol} / \mathrm{l})$ and C-ghrelin IR $(151 \pm 108 \mathrm{pmol} / \mathrm{l})$ decreased significantly within $60 \mathrm{~min}$ of feeding and remained suppressed for the entire $150 \mathrm{~min}$ of the study (maximum $35 \pm 12 \%$ reduction in plasma ghrelin at $t=$ $90 \mathrm{~min}$; maximum $38 \pm 14 \%$ reduction in C-ghrelin at $t=$ 120 min, both $P<0 \cdot 01$, Fig. 4B). Consistent with this observation, oral glucose administration also significantly suppressed fasting plasma ghrelin(1-28) (Fig. 5A) and C-ghrelin IR (Fig. 5B) over 120 min compared with control water administration $(P<0 \cdot 05)$. As we have previously described (Soule et al. 2005), $1 \mathrm{mg}$ i.m. glucagon significantly suppressed plasma ghrelin(1-28) concentrations compared with control saline administration $(P<0 \cdot 05$, Fig. 5C). In contrast, plasma C-ghrelin IR was not significantly suppressed by glucagon (Fig. 5D) although there was a trend for proghrelin(29-94)-like IR in the glucagon group to be lower than controls $(P=0 \cdot 10)$. Plasma $\mathrm{GH}$ concentrations peaked at $150-\mathrm{min}$ post-glucagon administration, an effect that was absent in saline controls (Fig. 5C and D).

\section{Distribution of proghrelin peptides in rat tissue and plasma}

Ghrelin(1-28), rat proghrelin(74-94) and obestatin(53-75) RIA IR concentrations in tissues and plasma from six fasted rats are summarised in Table 1. Both ghrelin(1-28) and proghrelin(74-94) IR had the same distribution profile, with highest concentrations observed in the stomach, followed by the duodenum and colon. proghrelin(74-94)-like IR was below assay detection limits in atrium, thyroid, ventricle and adrenal tissues. Surprisingly, rat obestatin(53-75) IR above detection limits was not observed in tissue extracts, including stomach (Table 1). Rat plasma ghrelin(1-28) IR was approximately one-third that of proghrelin(74-94) IR and one-half that of obestatin(53-75) IR (Table 1).

Molecular forms of proghrelin peptides in rat stomach and plasma

Ghrelin(1-28) IR in stomach extracts eluted as a single peak on SE-HPLC (Fig. 6A) consistent in size with previous reports (Kojima et al. 1999, Hosoda et al. 2000). In contrast, rat stomach proghrelin(74-94) IR consisted of two peaks; the first and major peak eluted at $\mathrm{M}_{\mathrm{r}} \sim 7000$, consistent in size with proghrelin(29-94), whereas the second and minor peak eluted 

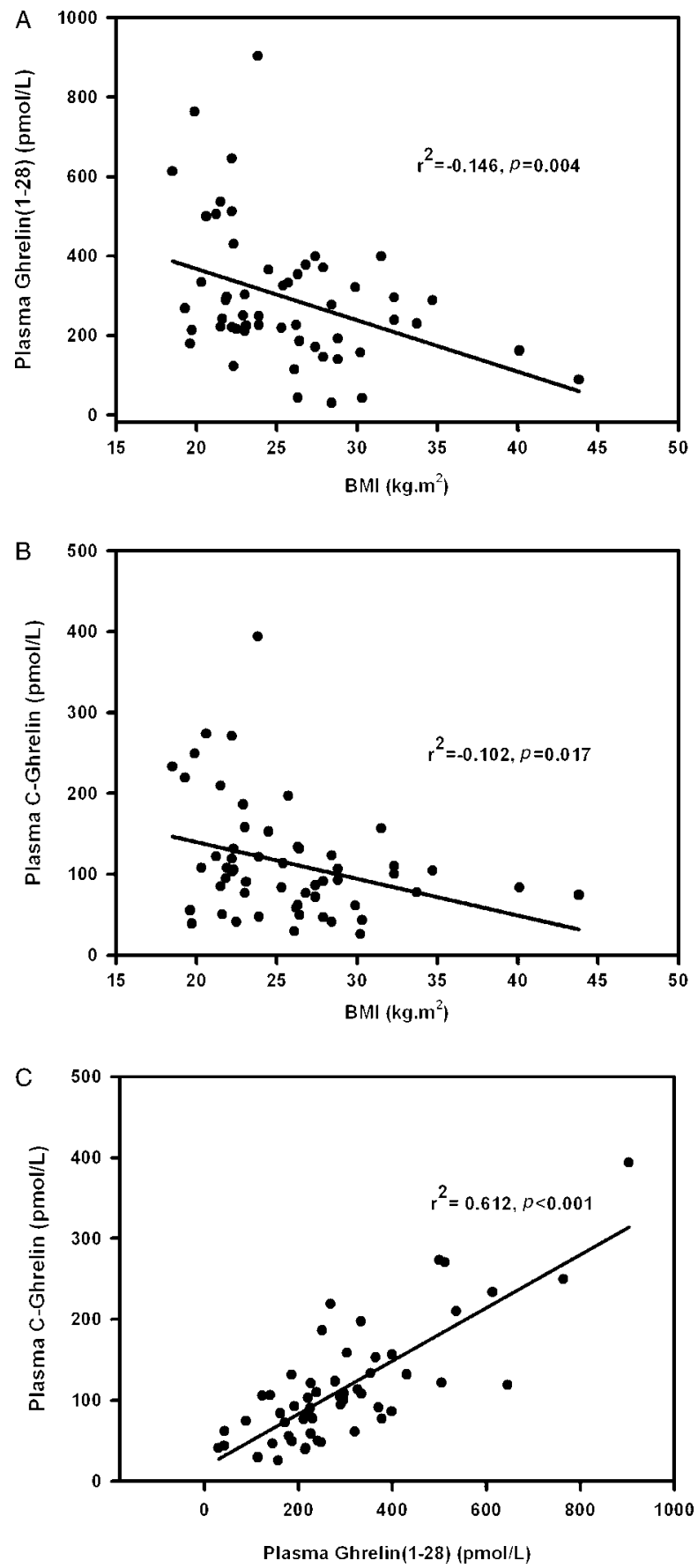

Figure 3 Plasma concentrations of ghrelin(1-28) IR (A) and Cghrelin IR (B) in healthy humans both had a negative correlation with BMI $(P<0.05$ for both). Accordingly, plasma ghrelin(1-28) IR and C-ghrelin IR had a strong positive correlation with each other $(P<0 \cdot 01, \mathrm{C})$.

at $\mathrm{M}_{\mathrm{r}} \sim 1600$ (Fig. 6A). obestatin(53-75) IR in these same SE-HPLC profiles was not detected (Fig. 6A). Subsequent RP-HPLC analysis of ghrelin(1-28) IR in rat stomach extracts identified three IR peaks, the largest of which eluted consistent
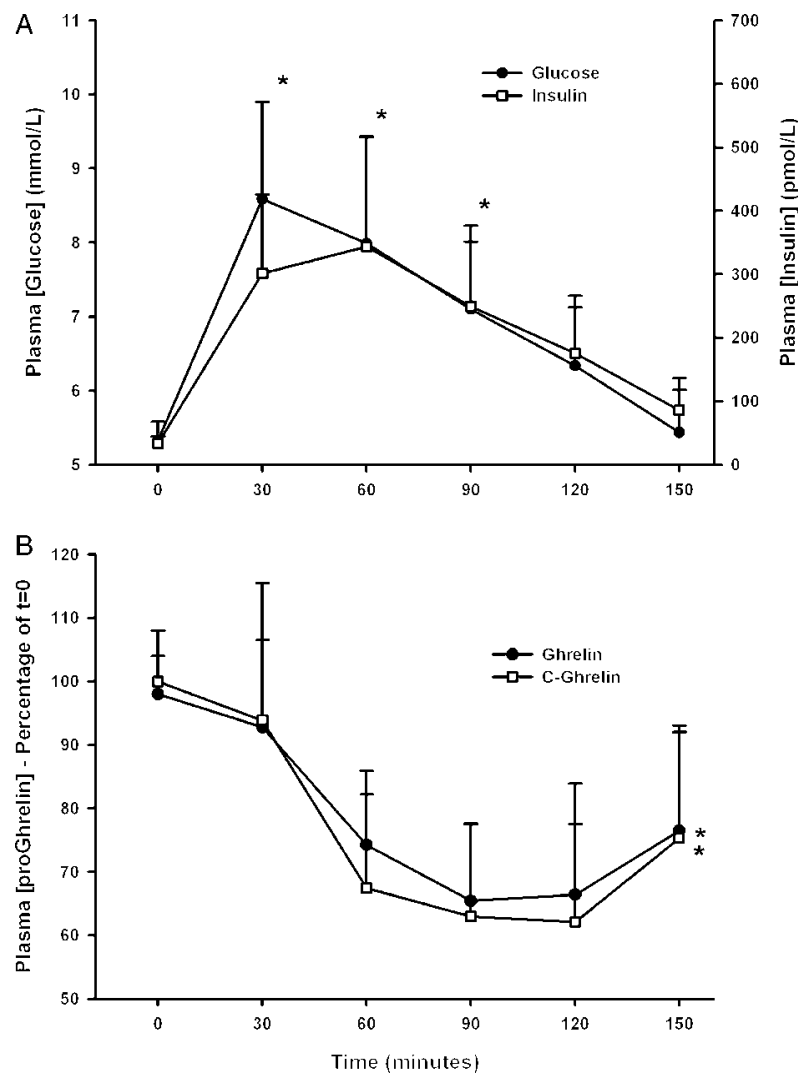

Figure 4 Response of plasma glucose and insulin (A) and ghrelin and C-ghrelin concentrations in humans $(n=8)$ for 150 min after ingestion of a standardised meal given at time 0 . Glucose and insulin concentrations significantly increased within $30 \mathrm{~min}$ (*both $P<0 \cdot 01, \mathrm{~A})$, whereas concomitant ghrelin and C-ghrelin concentrations significantly decreased (*both $P<0 \cdot 01, \mathrm{~B})$.

with octanoyl ghrelin(1-28), a minor peak of des-octanoyl ghrelin(1-28) and a third eluting three fractions after octanoyl ghrelin (Fig. 6C). The major IR proghrelin(74-94) peak on SE-HPLC $\left(\mathrm{M}_{\mathrm{r}} \sim 7000\right)$ eluted on RP-HPLC as a single peak, later than all obestatin and ghrelin markers (Fig. 6C). The minor IR proghrelin(74-94) SE-HPLC peak $\left(\mathrm{M}_{\mathrm{r}} \sim 1600\right)$ did not appear on RP-HPLC and was not investigated further.

SE-HPLC analysis of rat plasma extracts identified single IR peaks for both ghrelin(1-28) and proghrelin(74-94) IR, consistent with the major peaks observed in stomach extract SE-HPLC (Fig. 6B). The minor proghrelin(74-94) peak observed in rat stomach extracts $\left(\mathrm{M}_{\mathrm{r}} \sim 1600\right)$ was not observed in plasma extracts. Plasma ghrelin(1-28) IR comprised a single peak of $\mathrm{M}_{\mathrm{r}} \sim 3000$ (Fig. 6B). obestatin(53-75) IR in rat plasma extracts comprised interfering material at $\mathrm{M}_{\mathrm{r}} \sim 300$, with no true obestatin IR peak occurring at $\mathrm{M}_{\mathrm{r}} \sim 2500$ (Fig. 6B). RP-HPLC analysis of IR ghrelin(1-28) and proghrelin(74-94) in rat plasma extracts provided data consistent with that observed in RP-HPLC analysis of rat stomach extracts (Fig. 6D). 

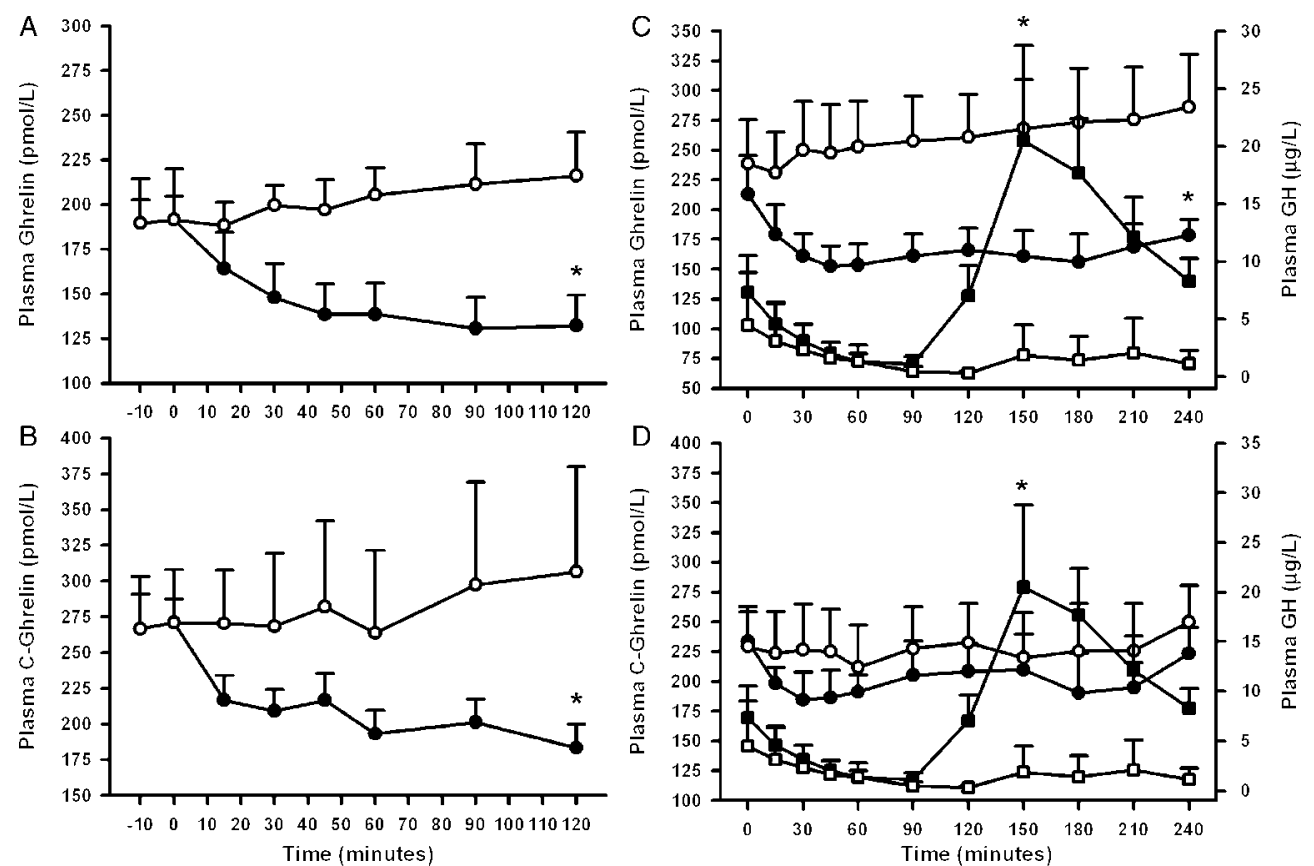

Figure 5 Plasma ghrelin ( $A$ and $C$ ) and C-ghrelin (B and D) concentrations in humans in response to oral glucose (A and B) and s.c. glucagon (C and D) stimulation. Both ghrelin (A) and C-ghrelin (B) concentrations were significantly suppressed by oral ingestion of 75 g glucose (filled circles, $* P<0 \cdot 05$ ) compared with control water ingestion (open circles). Plasma ghrelin concentrations (filled circles, C) were significantly suppressed within 60-min s.c. glucagon administration compared with control saline administration (open circles, C). In contrast, glucagon administration did not alter plasma C-ghrelin concentrations (filled circles) compared with control saline administration (open circles, D). GH concentrations peaked 150 min after glucagon administration $\left({ }^{*} P<0 \cdot 05\right.$, filled squares, $C$ and $\left.D\right)$, whereas saline controls showed no significant change (open squares, $C$ and D).

\section{Discussion}

The GH releasing and appetite-promoting hormone ghrelin comprises the first 28 amino acids of the proghrelin(1-94) peptide and has been intensively studied since its discovery in 1999 (Kojima et al. 1999, Korbonits et al. 2004, Kojima \&
Kangawa 2005). However, little is known about the circulating and tissue forms of putative peptides derived from the carboxyl terminus of proghrelin(1-94) (C-ghrelin).

Prior to performing endocrine manipulation studies, it was essential to define the circulating proghrelin species identified by each RIA. Therefore, consistent with previous reports

Table 1 Distribution and concentrations of proghrelin peptides in rat tissues and plasma using ghrelin(128), C-ghrelin(74-94) and obestatin(53-75) RIAs. Data are pmol/g per wet weight, mean \pm s.D.

\begin{tabular}{|c|c|c|c|}
\hline & ghrelin(1-28) RIA & C-ghrelin(74-94) RIA & obestatin(53-75) RIA \\
\hline \multicolumn{4}{|l|}{ Organ } \\
\hline Stomach & $454 \cdot 90 \pm 107 \cdot 50$ & $325 \cdot 44 \pm 241 \cdot 30$ & ND \\
\hline Duodenum & $11 \cdot 80 \pm 3 \cdot 90$ & $91 \cdot 42 \pm 44 \cdot 90$ & ND \\
\hline Pituitary & $4 \cdot 1 \pm 1 \cdot 3$ & $2 \cdot 4 \pm 1 \cdot 1$ & ND \\
\hline Colon & $0 \cdot 80 \pm 0 \cdot 60$ & $9 \cdot 70 \pm 8 \cdot 70$ & ND \\
\hline Kidney & $0 \cdot 20 \pm 0 \cdot 05$ & $3 \cdot 20 \pm 1 \cdot 40$ & ND \\
\hline Thymus & $0 \cdot 20 \pm 0 \cdot 16$ & $0 \cdot 40 \pm 0 \cdot 70$ & ND \\
\hline Submaxillary gland & $0 \cdot 20 \pm 0 \cdot 04$ & $12 \cdot 40 \pm 9 \cdot 47$ & ND \\
\hline Atrium & $0 \cdot 10 \pm 0 \cdot 07$ & ND & ND \\
\hline Thyroid & $0 \cdot 10 \pm 0 \cdot 0 \cdot 05$ & ND & ND \\
\hline Left ventricle & $0 \cdot 10 \pm 0 \cdot 03$ & ND & ND \\
\hline Adrenal gland & $0 \cdot 10 \pm 0 \cdot 03$ & ND & ND \\
\hline Plasma $(\mathrm{pmol} / \mathrm{l})$ & $57 \cdot 70 \pm 7 \cdot 70$ & $177 \cdot 70 \pm 20 \cdot 90$ & ND \\
\hline
\end{tabular}

ND, not detected. 

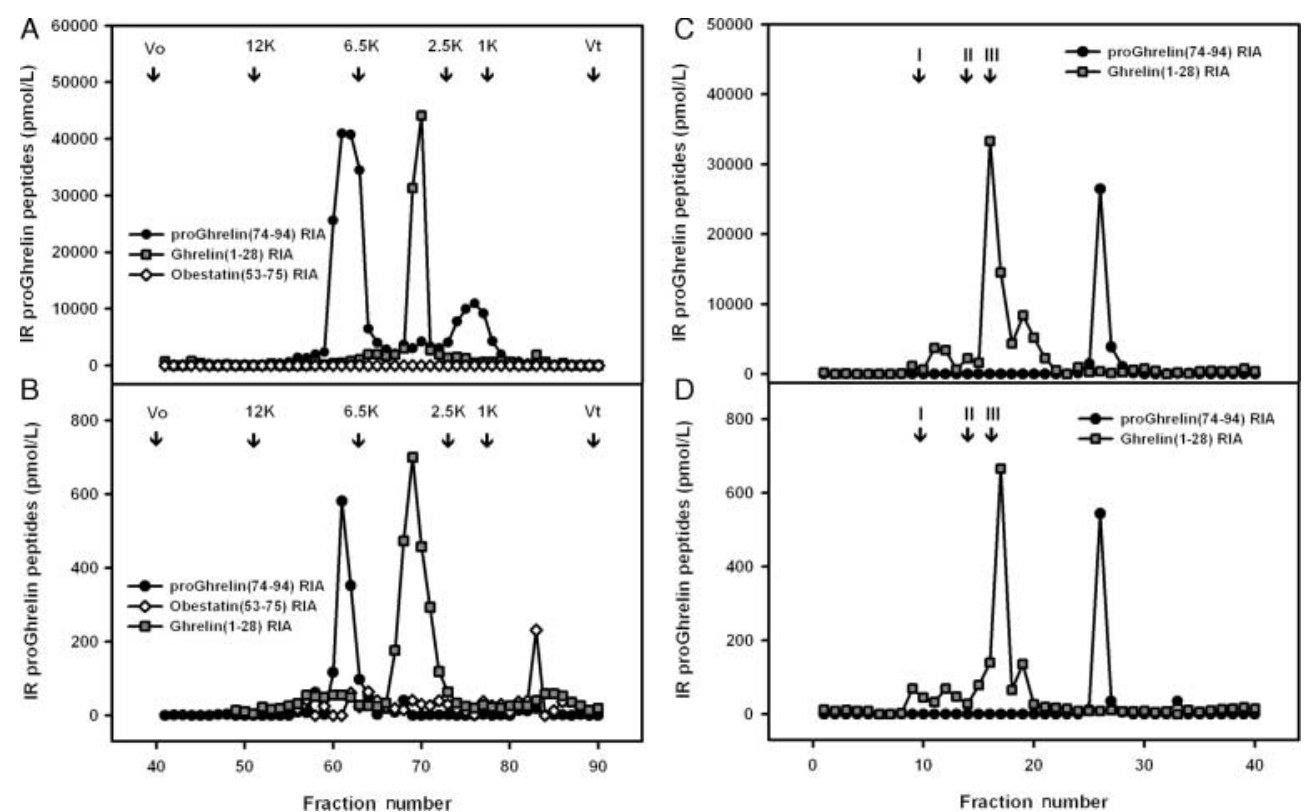

Figure 6 (A) In rat stomach, proghrelin(74-94) IR eluted as two peaks at $M_{r} \sim 7000$ and 1600 on SE-HPLC. IR ghrelin(1-28) eluted as a single peak at $M_{r} \sim 3000$. No IR obestatin(53-75) peaks were observed. (B) Rat plasma extracts contained a single peak of proghrelin(74-94) IR at $M_{r} \sim 7000$, ghrelin(1-28) IR at $M_{r} \sim 3000$ and obestatin(53-75) IR at $\mathrm{M}_{\mathrm{r}} \sim 300$ on SE-HPLC. Note that neither proghrelin(74-94) IR at $\mathrm{M}_{\mathrm{r}} \sim 1600$ nor proghrelin(1-94) IR at $M_{r} \sim 10000$ was observed. (C) RP-HPLC analysis of (A) IR ghrelin(1-28) identified desoctanoyl and octanoyl ghrelin eluting consistent with synthetic standards. IR proghrelin(74-94) from (A) eluted as a single peak, much later than column standards (I, des-octanoyl ghrelin; II, obestatin(53-75); III, octanoyl ghrelin). Note that proghrelin(74-94) IR at $M_{r} \sim 1600$ from (A) did not resolve on RP-HPLC. (D) Rat plasma ghrelin(1-28) IR from (B) eluted as des-octanoyl and octanoyl forms consistent with those observed in (C). Rat plasma proghrelin(74-94) IR from (B) also eluted a single peak consistent with that observed in (C). obestatin(53-75) IR from (B) did not bind to the RP-HPLC column.

(Kojima et al. 1999, Hosoda et al. 2000), the results from SE-HPLC/RP-HPLC coupled with specific RIA suggest that in human plasma IR ghrelin(1-28) at $\mathrm{M}_{\mathrm{r}} \sim 3000$ comprises two molecular species, with des-octanoyl ghrelin(1-28) being the major form. All three assays directed to the proghrelin(29-94) sequence, namely proghrelin(29-40), proghrelin(53-75) and proghrelin(74-94), detected the same single major peak on SE-HPLC at $\mathrm{M}_{\mathrm{r}} \sim 7000$, strongly suggesting that the entire $\mathrm{C}$-ghrelin peptide (proghrelin(29-94)) circulates in humans. We found no evidence for the existence of smaller peptides, including obestatin. Indeed, this latter assay only detected the proghrelin(29-94) peak on SE-HPLC at $\mathrm{M}_{\mathrm{r}} \sim 7000$. Both the ghrelin(1-28) and the proghrelin(74-94) RIAs detected a high molecular weight peak on SE-HPLC at a position consistent with the molecular weight of proghrelin(1-94), $\mathrm{M}_{\mathrm{r}} \sim 10000$. The lack of crossreactivity of our proghrelin(29-94) RIA with this peak is likely due to the antiserum requiring a free amino terminal group on residue 29 , evidenced by the lack of cross-reactivity of this antiserum with the $\mathrm{N}$-terminally extended peptide proghrelin(20-40) in cross-reactivity studies (Table 2 ). Taken together, our results show that ghrelin(1-28) and C-ghrelin(29-94) are the major peptides derived from the proghrelin precursor in the human circulation, with a minor circulating proghrelin component also present. Previously, we reported that circulating $\mathrm{C}$-ghrelin in the human circulation ranged between $M_{r} \sim 3500$ and 7000 (Pemberton et al. 2003). However, these preliminary results were based on a single C-ghrelin RIA (proghrelin(74-94)) and utilised a lower concentration of acetonitrile on SE-HPLC. Combination of proghrelin(29-40), proghrelin(53-75) and proghrelin(74-94) RIAs together with increasing the SE-HPLC acetonitrile concentration (from 20 to 60\%) resolved this discrepancy, suggesting that $\mathrm{C}$-ghrelin can interact non-specifically with SE-HPLC matrices unless sufficient organic solvent is present.

Fasting plasma levels of ghrelin(1-28) and C-ghrelin(2994) IR were positively correlated with one another and both were negatively correlated with BMI. We previously reported that plasma C-ghrelin IR did not appear to have any association with BMI (Pemberton et al. 2003), based upon measurements with our C-ghrelin(74-94) RIA which includes a small amount of proghrelin-like material in its measurement. In contrast, our present results - utilising our novel proghrelin(29-40) RIA, which detects only C-ghrelin(29-94)-like peptides - show that plasma C-ghrelin concentrations may have the same relationship with BMI as for ghrelin (Tschop et al. 2001, Shiiya et al. 2002). Consistent with previous reports (Ariyasu et al. 2001, 
Table 2 Cross-reactivity data (in percent) for human and rat ghrelin(1-28), proghrelin(29-40), ghrelin(74-94) and obestatin(53-75) RIAs

\begin{tabular}{|c|c|c|c|c|}
\hline & ghrelin(1-28) RIA & proghrelin(29-40) RIA & proghrelin(74-94) RIA & obestatin(53-75) RIA \\
\hline proghrelin(29-40) & $<0 \cdot 05$ & 100 & $<0 \cdot 01$ & $<0 \cdot 01$ \\
\hline proghrelin(20-40) & $<0 \cdot 10$ & $<0 \cdot 10$ & $<0.02$ & $<0 \cdot 01$ \\
\hline proghrelin(74-94) & $<0 \cdot 02$ & $<0 \cdot 01$ & 100 & $<0 \cdot 01$ \\
\hline obestatin(53-75) & $<0 \cdot 01$ & $<0 \cdot 01$ & $<0 \cdot 01$ & 100 \\
\hline Neuromedin $U$ & $<0 \cdot 02$ & $<0 \cdot 01$ & $<0.01$ & $<0.01$ \\
\hline Neuropeptide Y & $<0 \cdot 01$ & $<0 \cdot 01$ & $<0 \cdot 01$ & $<0 \cdot 01$ \\
\hline Vasoactive intestinal polypeptide & $<0 \cdot 01$ & $<0 \cdot 01$ & $<0 \cdot 01$ & $<0 \cdot 01$ \\
\hline Growth hormone-releasing hormone & $<0 \cdot 01$ & $<0 \cdot 01$ & $<0 \cdot 01$ & $<0 \cdot 01$ \\
\hline Orexin & $<0 \cdot 01$ & $<0 \cdot 01$ & $<0 \cdot 01$ & $<0 \cdot 01$ \\
\hline Glucagon-like peptide 1 & $<0 \cdot 01$ & $<0 \cdot 01$ & $<0 \cdot 01$ & $<0 \cdot 01$ \\
\hline
\end{tabular}

Cummings et al. 2001), our fasting-feeding study results show that human plasma concentrations of ghrelin are decreased after feeding. We extend this data to show that plasma $\mathrm{C}$-ghrelin concentrations are also decreased in response to feeding and our subsequent OGTT study suggests that glucose loading may be a common mechanism underlying these observations. Glucose/caloric loading may inhibit the secretion of ghrelin from the X/A-like cells in stomach mucosa (Tschop et al. 2000, Ariyasu et al. 2001, Shiiya et al. 2002). However, the exact pathways mediating glucoseinduced inhibition of ghrelin/C-ghrelin are presently unclear.

We have previously reported that increases in plasma ghrelin in humans are unlikely to be responsible for glucagon's induced increases in GH (Soule et al. 2005), although data from in vitro rat studies have demonstrated the ability of glucagon to stimulate ghrelin secretion from the stomach (Kamegai et al. 2004). In contrast with plasma ghrelin levels, $\mathrm{C}$-ghrelin levels tended to be lower in the glucagons-treated group, but this did not reach significance $(P=0 \cdot 10)$. This suggests that ghrelin secretion may be more sensitive to glucagon antagonism than $\mathrm{C}$-ghrelin secretion or that it may have a shorter half-life in the circulation. Presumably, $\mathrm{C}$-ghrelin is stored in the same stomach cell type (X/A) as ghrelin, but detailed secretion and clearance pattern studies as those done for ghrelin (Cummings et al. 2001) have not been reported. Our results do not preclude C-ghrelin from having a direct action upon $\mathrm{GH}$-secretion; rather - like ghrelin - it is unlikely to be a direct stimulus for $\mathrm{GH}$ in the clinical setting of s.c. glucagon stimulation. Elucidation of any biological effects of C-ghrelin upon GH secretion and other hormonal/ haemodynamic parameters will require yet more precise identification of the circulating peptide (including identification of putative post-translational modifications as known for ghrelin) followed by dose-response studies.

We found the distribution of IR C-ghrelin in rat tissues to be equivalent with that of ghrelin and that the stomach and gastrointestinal tract contain the highest concentrations on a pmol/g per wet weight basis. This is in agreement with previous reports describing the gene expression and immunoreactive peptide levels of ghrelin in rats (Kojima et al. 1999, Hosoda et al. 2000) and humans (Date et al. 2000, Ariyasu et al. 2001). Therefore, like ghrelin, it is probable that the primary source of circulating C-ghrelin is the stomach. We did not detect IR C-ghrelin in heart, thyroid or adrenal samples, but we cannot exclude the presence of the peptide in these tissues. To our surprise, we did not detect IR obestatin in rat stomach tissue extracts, instead observing only a proghrelin(29-94)-like peptide on SE-HPLC. The reason for this is unclear, as the rat obestatin RIA purchased from Phoenix Pharmaceuticals recognised synthetic amidated rat obestatin added to plasma samples and synthetic obestatin peptide was well recovered (>80\%) through our extraction procedures. A recent report, utilising the same commercial obestatin RIA as we used, documented stomach concentrations of IR obestatin to be $0 \cdot 2 \%$ those of IR ghrelin(1-28) in 21-day-old perinatal rats (Chanoine et al. 2006) although the molecular form was not described. These, and our, results contrast markedly with those of Zhang et al. (2005) who reported an approximate 2:1 ratio of IR ghrelin(1-28) to obestatin in rat stomach extracts subjected to G50 Sephadex chromatography.

Rat stomach and plasma ghrelin(1-28) IR eluted on HPLC/RIA consistent with the octanoyl form, with only a small amount of des-octanoyl form detected. This suggests our antibody was more specific to the octanoyl form as previous work has clearly shown that rat stomach extracts contain approximately a 1:1 ratio of octanoyl:des-octanoyl ghrelin(1-28), whereas rat plasma contains more than $90 \%$ of des-octanoyl form (Kojima et al. 1999, Hosoda et al. 2000). Therefore, it is possible that our rat tissue and plasma ghrelin concentration data underestimate true endogenous levels of the hormone.

Several recent studies have not been able to reproduce the originally reported anti-orexigenic effects of obestatin 
(Gourcerol et al. 2006, Nogueiras et al. 2006, Samson et al. 2006), the ability of obestatin to activate GPR 39 receptors has also not been reproduced (Holst et al. 2006) and GPR39 receptor transcripts have not been found in the hypothalamus (Jackson et al. 2006, Nogueiras et al. 2006), a logical target organ of obestatin. Therefore, in combination with our data which does not support the existence of obestatin peptide in humans or rats, the accumulating evidence does not support the concept of ghrelin and obestatin as physiological antagonists (Zhang et al. 2005).

In summary, utilising a four RIA approach, we have documented immunoreactive proghrelin(1-94)-derived peptides in mammalian tissues and plasma. We report that the stored and circulating form of C-ghrelin in rats and humans is C-ghrelin(29-94)-like material and that the tissue distribution of $\mathrm{C}$-ghrelin matches that of ghrelin. Therefore, it is probable that the stomach is the main source of circulating C-ghrelin. We did not either find any evidence for obestatin peptides, circulating as distinct entities in the human and rat circulation, or as a secretable hormone in rat tissues. In agreement with our previous work (Soule et al. 2005), it appears unlikely that peptides derived from proghrelin(1-94) are responsible for exogenous glucagon stimulation-induced increases in plasma $\mathrm{GH}$ in humans. Finally, immunoreactive $\mathrm{C}$-ghrelin in the human circulation is positively correlated with plasma levels of ghrelin, and fasting blood levels, also like ghrelin are negatively correlated with BMI. Both ghrelin and C-ghrelin in humans are reduced by nutritional intake, and glucose is one potential mechanism responsible for this.

\section{Acknowledgements}

We acknowledge the excellent assistance of the technical staff of Endolab Laboratories, Christchurch Hospital in hormone measurement and the Special Tests nursing staff of the Department of Endocrinology, Christchurch Hospital in human endocrine studies. This work was supported by the Health Research Council and National Heart Foundation of New Zealand. A M R holds the National Heart Foundation of New Zealand Professorial Chair of Cardiovascular Studies. The authors declare there is no conflict of interest which would prejudice the impartiality of this scientific work.

\section{References}

Ariyasu H, Takaya K, Tagami T, Ogawa Y, Hosoda K, Akamizu T, Suda M, Koh T, Natsui K, Toyooka S et al. 2001 Stomach is a major source of circulating ghrelin, and feeding state determines plasma ghrelin-like IR levels in humans. Journal of Clinical Endocrinology and Metabolism $\mathbf{8 6}$ 4753-4758

Broglio F, Gottero C, Prodam F, Gauna C, Muccioli G, Papotti M, Abribat T, Van Der Lely AJ \& Ghigo E 2004 Non-acylated ghrelin counteracts the metabolic but not the neuroendocrine response to acylated ghrelin in humans. Journal of Clinical Endocrinology and Metabolism 89 3062-3065.
Chanoine JP, Wong ACK \& Barrios V 2006 obestatin, acylated and total ghrelin concentrations in the perinatal rat pancreas. Hormone Research 66 81-88.

Cummings DE, Purnell JQ, Frayo RS, Schmidova K, Wisse BE \& Weigle DS 2001 A pre-prandial rise in plasma ghrelin levels suggests a role in meal initiation in humans. Diabetes 50 1714-1719.

Date Y, Kojima M, Hosoda H, Sawaguchi A, Mondal MS, Suganuma T, Matsukura S, Kangawa K \& Nakazato M 2000 ghrelin, a novel growth hormone-releasing acylated peptide, is synthesized in a distinct endocrine cell type in the gastrointestinal tracts of rats and humans. Endocrinology 141 4255-4261.

Gourcerol G, Million M, Adelson DW, Wang Y, Wang L, Rivier J, St-Pierre DH \& Tache Y 2006 Lack of interaction between peripheral injection of CCK and obestatin in the regulation of gastric satiety signalling in rodents. Peptides 27 2811-2819.

Holst B, Egerod KL, Schild E, Vickers SP, Cheetham S, Gerlach LO, Storjohann L, Stidsen CE, Jones R, Beck-Sickinger AG et al. 2006 GPR 39 signalling is stimulated by zinc ions but not by obestatin. Endocrinology (In press)

Hosoda H, Kojima M, Matsuo H \& Kangawa K 2000 ghrelin and des-acyl ghrelin: two major forms of rat ghrelin peptide in gastrointestinal tissue. Biochemical and Biophysical Research Communications 279 909-913.

Jackson VR, Nothacker HP \& Civelli O 2006 GPR39 receptor expression in the mouse brain. Neuroreport 17 813-816.

Kamegai J, Tamura H, Shimizu T, Ishii S, Sugihara H \& Oikawa S 2004 Effects of insulin, leptin, and glucagon on ghrelin secretion from isolated perfused rat stomach. Regulatory Peptides 119 77-81.

Kojima M \& Kangawa K 2005 ghrelin: structure and function. Physiological Reviews 85 495-522.

Kojima M, Hosoda H, Date Y, Nakazato M, Matsuo H \& Kangawa K 1999 ghrelin is a growth-hormone-releasing acylated peptide from stomach. Nature 402 656-660.

Korbonits M, Goldstone AP, Gueorguiev M \& Grossman MB 2004 ghrelin - a hormone with multiple functions. Frontiers in Neuroendocrinology 25 27-68.

Nogueiras R, Pfluger P, Tovar S, Myrtha A, Mitchell S, Morris A, Perez-Tilve D, Vázquez MJ, Wiedmer P, Castañeda TR et al. 2006 Effects of obestatin on energy balance and growth hormone secretion in rodents. Endocrinology (In press)

Pemberton C, Wimalasena P, Yandle T, Soule S \& Richards M 2003 $\mathrm{C}$-terminal pro-ghrelin peptides are present in the human circulation. Biochemical and Biophysical Research Communications 310 567-573.

Pemberton CJ, Tokkola H, Bagi Z, Koller A, Pontinen J, Ola A, Vuolteenaho O, Szokodi I \& Ruskoaho H 2004 ghrelin induces vasoconstriction in the rat coronary vasculature without altering cardiac peptide production. American Journal of Physiology 287 H1522-H1529.

Samson WK, White MM, Price C \& Ferguson AV 2006 obestatin acts in brain to inhibit thirst. American Journal of Physiology (In press).

Shiiya T, Nakazato M, Mizuta M, Date Y, Mondal MS, Tanaka M, Nozoe S, Hosoda H, Kangawa K \& Matsukura S 2002 Plasma ghrelin levels in lean and obese humans and the effect of glucose on ghrelin secretion. Journal of Clinical Endocrinology and Metabolism 87 240-244.

Soule S, Pemberton C, Hunt P, Cole D, Raudsepp S \& Inder W 2005 Prandial regulation of ghrelin secretion in humans: does glucagon contribute to the preprandial increase in circulating ghrelin? Clinical Endocrinology 63 412-417.

Sun Y, Wang P, Zheng H \& Smith R 2004 ghrelin stimulation of growth hormone release is mediated through the growth hormone secretagogue receptor. PNAS 101 4679-4684.

Thompson NM, Gill DA, Davies R, Loveridge N, Houston PA, Robinson IC \& Wells T 2004 ghrelin and des-octanoyl ghrelin promote adipogenesis directly in vivo by a mechanism independent of the type 1a growth hormone secretagogue receptor. Endocrinology 145 234-242.

Toshinai K, Yamaguchi H, Sun Y, Smith RG, Yamanaka A, Sakurai T, Date Y, Mondal MS, Shimbara T, Kawagoe T et al. 2006 Des-acyl ghrelin induces food intake by a mechanism independent of the growth hormone secretagogue receptor. Endocrinology 147 2306-2314.

Tschop M, Smiley DL \& Heiman M 2000 ghrelin induces adiposity. Nature 407 908-913. 
Tschop M, Weyer C, Tataranni PA, Devanarayan V, Ravussin E \& Heiman ML 2001 Circulating ghrelin levels are decreased in human obesity. Diabetes $\mathbf{5 0}$ 707-709.

van der Lely AJ, Tschop M, Heiman ML \& Ghigo E 2004 Biological, physiological, pathophysiological and pharmacological aspects of ghrelin. Endocrine Reviews 25 426-457.

Wren AM, Small CJ, Ward HL, Murphy KG, Dakin CL, Taheri S, Kennedy AR, Roberts GH, Morgan DG, Ghatei MA et al. 2000 ghrelin enhances appetite and increases food intake in humans. Endocrinology 141 4325-4328.
Zhang JV, Ren EG, Avsian-Ktretchmer O, Luo CW, Ruach R, Klein C \& Hseuh AJW 2005 obestatin, a peptide encoded by the ghrelin gene, opposes ghrelin's effects on food intake. Science 310 996-999.

Received in final form 28 September 2006 Accepted 30 October 2006

Made available online as an Accepted Preprint 13 November 2006 